\title{
UPAYA MENINGKATKAN KETERAMPILAN BERBASIS PROYEK DAN HASIL BELAJAR IPA DENGAN MENERAPAKAN MODEL PEMBELAJARAN PROJECT BASED LEARNING (PJBL) MATERI REPRODUKSI TUMBUHAN DI KELAS IX SMP NEGERI 1 STABAT
}

\author{
Suriyadi \\ Guru IPA SMP Negeri 1 Stabat \\ Jl. Zainul Arifin No.10, Kwala Bingai, Kab. Langkat, Sumatera Utara 20811 \\ E-mail: suriyadiandi@gmail.com
}

\begin{abstract}
ABSTRAK
Tujuan penelitian ini adalah: 1) Untuk mengetahui peningkatan keterampilan berbasis proyek siswa setelah penerapan model pembelajaran Project Based Learning (PjBL) di IX-A SMP Negeri 1 Stabat Kab. Langkat T.P. 2017/2018; 2) Untuk mengetahui peningkatan hasil belajar siswa setelah penerapan model pembelajaran Project Based Learning (PjBL) di kelas IX-A SMP Negeri 1 Stabat Kab. Langkat T.P. 2017/2018. Penelitian ini dilaksanakan dalam kelas meliputi kegiatan pelaksanaan tindakan kelas (PTK) berupa kegiatan refleksi awal dan melakukan observasi untuk mengidentifikasi permasalahan yang terjadi di kelas, perencanaan pembelajaran, pelaksanaan tindakan, observasi dan refleksi. Adapun temuan penelitian PTK ini adalah 1) Pada siklus I dari 5 kelompok pada siklus I keterampilan berbasis proyek semua kelompok memperoleh kategori cukup, dari hasil observasi ditemukan kualitas proyek yang direncanakan masuk kategori cukup, untuk aspek Keakuratan data, Kuantitas dan kualitas data dan Analisis data juga kategori cukup. Pada siklus II diperoleh 5 kelompok pada siklus II keterampilan berbasis proyek semua kelompok memperoleh kategori Sangat baik; 2) Pada siklus I dari 38 orang siswa diperoleh 27 orang yang tuntas dengan 71,1\% dan 11 orang yang tidak tuntas dengan 28,9\%, dan pada siklus II dari 38 orang siswa diperoleh 35 orang yang tuntas dengan 92,1\% dan 3 orang yang tidak tuntas dengan $7,8 \%$.
\end{abstract}

Kata Kunci: Model Pembelajaran, Project Based Learning (PjBL)

\begin{abstract}
The objectives of this study were: 1) To determine the improvement of student project-based skills after the application of the Project Based Learning (PjBL) learning model at IX-A State Middle School 1 Stabat, Kab. Langkat T.P. 2017/2018; 2) To find out the improvement in student learning outcomes after the application of the Project Based Learning (PjBL) learning model in class IX-A of SMP Negeri 1 Stabat, Kab. Langkat T.P. 2017/2018. This research was carried out in the classroom covering classroom action activities (PTK) in the form of initial reflection activities and conducting observations to identify problems that occur in the classroom, planning learning, implementing actions, observation and reflection. The findings of this PTK study are 1) In cycle I of 5 groups in the first cycle of project-based skills all groups obtained enough categories, from observations it was found that the quality of the planned project was insufficient category, for aspects of data accuracy, data quantity and quality and data analysis also enough categories. In the second cycle, there were 5 groups in the project-based cycle II of skill, all groups obtained a very good category; 2) In the first cycle of 38 students obtained 27 people who completed $71.1 \%$ and 11 people who did not complete with $28.9 \%$, and in the second cycle of 38 students obtained 35 people who completed with $92.1 \%$ and 3 people who did not complete with $7.8 \%$.
\end{abstract}

Keywords : Models, Project Based Learning (PjBL) 


\section{PENDAHULUAN}

Pendidikan memiliki tujuan penting yaitu menumbuh kembangkan potensi yang dimiliki siswa, selain itu pendidikan juga bertujuan untuk mencerdaskan kehidupan bangsa, sehingga siswa memiliki kemampuan dan keterampilan serta menjadi manusia yang berguna bagi bangsa dan negara. Oleh karena itu, setiap pendidik berkewajiban untuk memenuhi tuntutan tersebut dengan menciptakan suasana belajar mengajar yang baik dan efektif. Dalam konteks penyelenggaraan ini, guru dengan sadar merencanakan kegiatan pengajaran secara sistematis dan berpedoman pada seperangkat aturan dan rencana tentang pendidikan yang dikemas dalam bentuk kurikulum (Depdiknas, 2003).

Pembelajaran IPA merupakan pembelajaran yang menarik dan menyenangkan serta berkaitan dengan kehidupan sehari-hari. IPA mengandung makna pengajuan pertanyaan, pencarian jawaban, pemahaman jawaban, penyempurnaan jawaban baik tentang gejala maupun karakteristik alam sekitar melalui cara-cara sistematis. Pembelajaran sains pada hakekatnya terdiri atas tiga komponen, yaitu produk, proses, dan sikap ilmiah.

Ilmu Pengetahuan Alam (IPA) selain sebagai produk juga sebagai proses tidak dapat dipisahkan satu sama lain, sehingga dalam hal ini diperlukan keaktifan siswa dalam proses pembelajaran. Siswa harus dilibatkan secara aktif berpartisipasi dalam kegiatan pembelajaran, karena itu dibutuhkan suatu metode pembelajaran yang dapat meningkatkan keaktifan siswa sehingga prestasi belajar siswa dapat meningkat. Salah satu metode pembelajaran yang dapat meningkatkan keterampilan dan keaktifan siswa adalah metode pembelajaran berbasis proyek. Pembelajaran berbasis proyek (project-based learning) adalah sebuah model atau pendekatan pembelajaran yang inovatif, yang menekankan belajar kontekstual melalui kegiatan-kegiatan yang kompleks.

Fokus pembelajaran terletak pada konsepkonsep dan prinsip-prinsip inti dari suatu disiplin studi, melibatkan siswa dalam investigasi pemecahan masalah dan kegiatan tugas-tugas bermakna lain, memberi kesempatan siswa bekerja secara otonom mengkonstruk pengetahuan mereka sendiri, dan mencapai puncaknya menghasilkan produk nyata. Contoh dari produk nyata yang dihasilkan misalnya alat peraga IPA. Alat peraga dapat memberikan pemahaman yang lebih dalam terhadap materi yang sedang dibahas, karena siswa dapat memperoleh pengalaman yang nyata, dapat menumbuhkan pemikiran yang teratur dan berkesinambungan, membantu berkembangnya kemampuan berbahasa, memberikan pengalaman belajar yang lebih sempurna.

Di sekolah Menengah Pertama (SMP) umumnya dalam proses pembelajaran menggunakan pendekatan saintifik walaupun belum maksimal diterapkan lebih banyak menerapkan metode pembelajaran konvensional yang cenderung bersifat searah, sehingga siswa terlihat kurang aktif. Proses pembelajaran IPA yang tidak menggunakan media gambar, sumber belajar dan alat peraga membuat siswa sulit untuk menerima dan memahami materi pelajaran, membuat siswa tidak aktif dan tidak terbiasa mengerjakan sebuah proyek yang menghasilkan sebuah produk.

Hasil refleksi yang dilakukan selama ini mengajar di SMP Negeri 1 Stabat Kab. Langkat Provinsi Sumatera Utara, proses pembelajaran yang berlangsung selama ini masih Teacher center, artinya masih berpusat kepada siswa sehingga siswa tidak aktif dalam mengikuti proses belajar mengajar IPA. Metode yang sering digunakan guru masih metode ceramah dan kurang mengimplementasikan model pembelajaran di kelas, sehingga pembelajaran dirasa kurang menarik minat belajar siswa. Hal inilah yang menyebabkan siswa pasif dan bergurau sendiri dengan teman pada saat pembelajaran berlangsung. Hasil observasi minat belajar siswa kurang antusias dalam pembelajaran karena penyampaian materi dari guru dirasa membuat siswa menjadi jenuh dan bosan. Minat siswa kurang yang disebabkan siswa takut untuk bertanya sehingga guru menganggap siswa sudah paham. Cara yang dapat ditempuh agar siswa dapat terlibat aktif dalam proses pembelajaran yaitu dengan memusatkan pembelajaran kepada siswa (student centered).

Salah satu alternatif pendekatan yang dikembangkan dan dapat dipakai dalam proses pembelajaran yaitu dengan model pembelajaran Project Based Learning (PJBL). PjBL adalah suatu model pembelajaran yang melibatkan suatu proyek yang dikerjakan secara individual atau kelompok dan dilaksanakan dalam jangka waktu tertentu. PjBL yang dilakukan secara kolaboratif akan menghasilkan suatu produk pembelajaran yang nantinya akan di presentasikan di depan kelas (Asan \& Haliloglu, 2005). Salah satu model pendekatan saintifik yang dapat meningkatkan hasil belajar IPA adalah model pembelajaran Project Based Learning (PjBL). PjBL merupakan model intruksional yang berbasis masalah 
dan berpusat pada siswa (student centered). Dalam PjBL para siswa diharuskan menggunakan penyelidikan, penelitian, perencanaan, keterampilan dan kemampuan memecahkan masalah pada saat penyelesaian proyek (Aritonang, 2008)

Dari latar belakang masalah diatas, peneliti ingin melakukan perbaikan pembelajaran dengan melakukan Penelitian Tindakan Kelas (PTK) diharapkan dengan penerapan model pembelajaran Project Based Learning (PJBL) dapat meningkatkan keterampilan proyek dan hasil belajar siswa pada mata pelajaran IPA. Adapun tujuan dari penelitian tindakan kelas ini adalah: 1) Untuk mengetahui peningkatan keterampilan berbasis proyek siswa setelah penerapan model pembelajaran Project Based Learning (PjBL) di IX-A SMP Negeri 1 Stabat Kab. Langkat T.P. 2017/2018; 2) Untuk mengetahui peningkatan hasil belajar siswa setelah penerapan model pembelajaran Project Based Learning ( $\mathrm{PjBL}$ ) di kelas IX-A SMP Negeri 1 Stabat Kab. Langkat T.P. $2017 / 2018$.

\section{METODE PENELITIAN}

Desain PTK merupakan kegiatan pemecahan masalah yang bercirikan siklik dan reflektif yang dimulai dari 1) perencanaan (planning), 2) pelaksanaan tindakan (action), 3) mengumpulkan data (observing), dan 4) menganalisis data atau informasi untuk memusatkan sejauh mana kelebihan atau kelemahan tindakan tersebut. PTK ini ditandai dengan adanya perbaikan terus-menerus yang dilakukan pada setiap siklus sehingga sasaran peneliti tercapai, serta pelaksanaan penelitian ini direncanakan 2 siklus.

\section{HASIL DAN PEMBAHASAN}

Siklus I

Proses belajar mengajar menggunakan model pembelajaran Project Based Learning (PjBL) yang dilakukan pada materi pertemumbuhan dan perkembangan di kelas IX-A SMP Negeri I Langkat dengan Kriteria Belajar Minimal Mata pelajaran Biologi $(K B M=75)$ diperoleh hasil belajar siswa tertera pada gambar 1 dibawah ini.

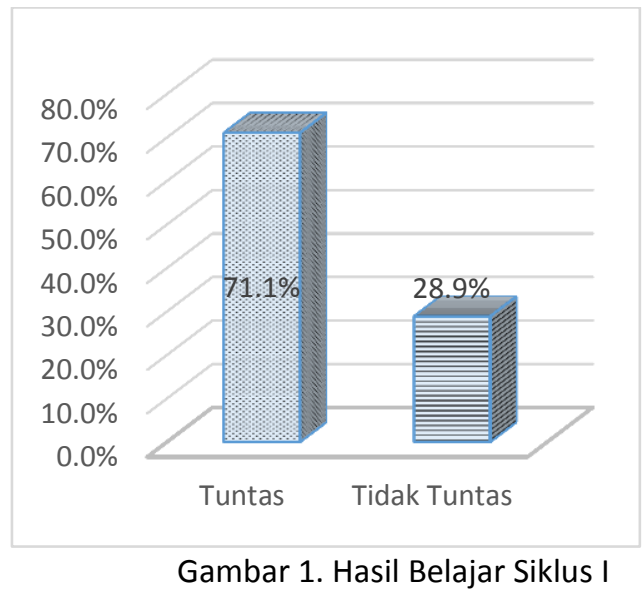

Gambar 1 diatas diperoleh hasil belajar IPA kelas IX-A SMP Negeri 1 Stabat Kab. Langkat Tahun Pelajaran 2017/2018, dapat ditarik kesimpulan bahwa pembelajaran dengan menggunakan model pembelajaran Project Based Learning (PjBL) untuk meningkatkan hasil belajar dari 38 orang siswa diperoleh 27 orang yang tuntas dengan 71,1\% dan 11 orang yang tidak tuntas dengan $28,9 \%$. Hasil belajar ini masih tergolong rendah jika di ukur dari ketuntasan klasikal siswa, ini disebabkan penerapan model pembelajaran Project Based Learning ( $\mathrm{PjBL}$ ) dilaksanakan guru dan siswa juga belum terbiasa, ini dapat dilihat dari hasil observasi keterampilan berbasis proyek yang hasil observasi keterampilan berbasis proyek yang dilakukan siswa yang terbagi menjadi 5 kelompok pada siklus I keterampilan berbasis proyek semua kelompok memperoleh kategori cukup, dari hasil observasi ditemukan kualitas proyek yang direncanakan masuk kategori cukup, untuk aspek Keakuratan data, Kuantitas dan kualitas data dan Analisis data juga kategori cukup, hasil wawancara yang dilakukan kepada siswa, mereka mengatakan bahwa belum terbiasa mengambil data dan mengolah data secara mandiri. Untuk aspek presentase juga siswa masuk kategori cukup, ini juga dikarenakan siswa belum terbiasa mempresentasikan hasil kerjanya di depan kelas dengan baik.

\section{Siklus II}

Proses belajar mengajar menggunakan model pembelajaran Project Based Learning (PjBL) yang dilakukan pada materi pertemumbuhan dan perkembangan di kelas IX-A SMP Negeri 1 Stabat Kab. Langkat, dengan Kriteria Belajar Minimal Mata pelajaran Biologi (KBM=75) diperoleh hasil belajar siswa tertera pada gambar 2 dibawah ini. 


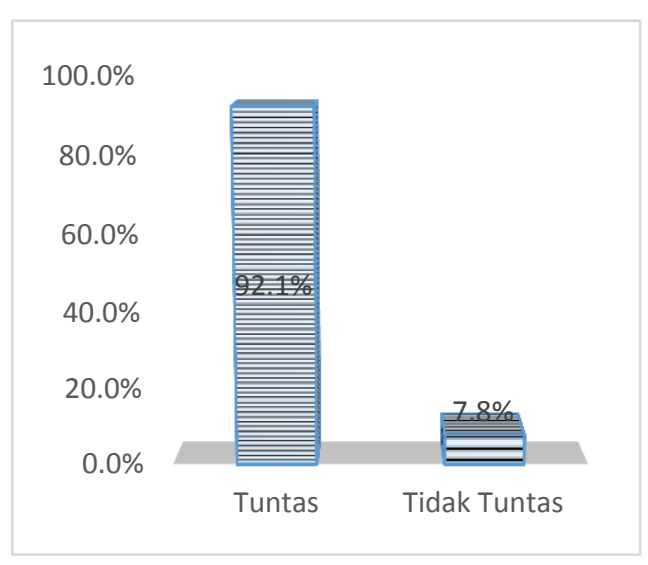

Gambar 2 Hasil Belajar Siklus II

Gambar 2 diatas diperoleh hasil belajar biologi kelas IX-A SMP Negeri 1 Stabat Kab. Langkat Tahun Pelajaran 2017/2018, dapat ditarik kesimpulan bahwa pembelajaran dengan menggunakan model pembelajaran Project Based Learning (PjBL) untuk meningkatkan hasil belajar dari 38 orang siswa diperoleh 30 orang yang tuntas dengan 92,1\% dan 3 orang yang tidak tuntas dengan $7,8 \%$. Hasil belajar ini dapat ditarik kesimpulan bahwa siklus II dengan menerapkan model pembelajaran Project Based Learning ( $\mathrm{PjBL})$ berhasil dengan baik, dengan peningkatan telah melewati ketuntasan klasikal, hasil ini juga sejalan dengan hasil observasi keterampilan berbasis proyek yang hasil observasi keterampilan berbasis proyek yang dilakukan siswa yang terbagi menjadi 5 kelompok pada siklus II keterampilan berbasis proyek semua kelompok memperoleh kategori Sangat baik, ini disebabkan temuan pada siklus 1 dimana siswa belum terbiasa, jadi pada saat proses pembelajaran pada siklus II dilakukan pendampingan langsung oleh guru dengan dibimbingan dengan arahan yang baik.

Setelah melaksanakan penelitian tindakan kelas dengan menerapkan model pembelajaran Project Based Learning (PjBL) di kelas IX-A SMP Negeri 1 Stabat, Kab. Langkat. Dengan materi Reproduksi pada tumbuhan, dapat dilihat peningkatan keberhasilan dari siklus I dan siklus II dibawah ini.

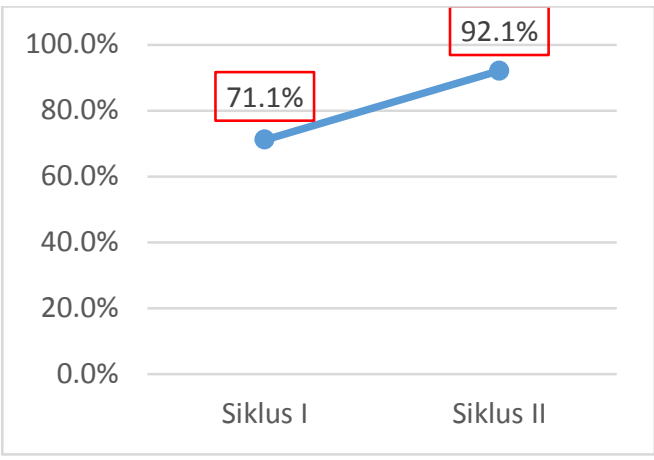

Gambar 3. Perbandingan Siklus I dan Siklus II

Dari gambar 3 diatas menunjukan terjadinya peningkatan hasil belajar siswa kelas IX-A SMP Negeri 1 Stabat Kab. Langkat dengan menerapkan Project Based Learning (PjBL) dari siklus I dari 71,1\% menjadi $92,1 \%$. adapun temuan penelitian tindakan kelas ini adalah PjBL merupakan metode pembelajaran yang dapat menyelesaikan kendala sesuai dengan permasalahan yang diidentifikasi yang melibatkan aktivitas siswa dalam proses pembelajaran serta mempermudah siswa dalam memahami materi pelajaran, karena siswa melakukan proyek percobaan tentang pertumbuhan dan perkembangan sehingga siswa mengalami sendiri. Dapat disimpulkan bahwa PjBL dapat meningkatkan hasil belajar siswa sesuai dengan temuan penelitian Nadhiroh, (2016) Hasil penelitian menunjukkan bahwa keterampilan metakognitif dan hasil belajar siswa meningkat melalui model pembelajaran PjBL. Peningkatan tersebut dapat dilihat dari kenaikan persentase keterampilan metakognitif dan hasil belajar dari siklus I ke siklus II.

Dilihat dari aspek keterampilan berbasis proyek pada siklus I dari 5 kelompok pada siklus I keterampilan berbasis proyek semua kelompok memperoleh kategori cukup, dari hasil observasi ditemukan kualitas proyek yang direncanakan masuk kategori cukup, untuk aspek Keakuratan data, Kuantitas dan kualitas data dan Analisis data juga kategori cukup, hasil wawancara yang dilakukan kepada siswa, mereka mengatakan bahwa belum terbiasa mengambil data dan mengolah data secara mandiri. Untuk aspek presentase juga siswa masuk kategori cukup. Sedangkan pada siklus II diperoleh 5 kelompok pada siklus II keterampilan berbasis proyek semua kelompok memperoleh kategori Sangat baik. Dapat ditarik kesimpulan bahwa penerapan model pembelajaran PjBL dapat meningkatkan keterampilan berbasis proyek, hal ini juga sejalan dengan temuan penelitian Fatmawati, (2014) yang mengatakan model 
pembelajaran PjBL menunjukkan dapat meningkatkan indikator keterampilan berbasis proyek.

\section{KESIMPULAN}

Berdasarkan temuan hasil penelitian dapat ditarik kesimpulan Pada siklus I dari 5 kelompok pada siklus I keterampilan berbasis proyek semua kelompok memperoleh kategori cukup, dari hasil observasi ditemukan kualitas proyek yang direncanakan masuk kategori cukup, untuk aspek Keakuratan data, Kuantitas dan kualitas data dan Analisis data juga kategori cukup. Pada siklus II diperoleh 5 kelompok pada siklus II keterampilan berbasis proyek semua kelompok memperoleh kategori Sangat baik. Pada siklus I dari 38 orang siswa diperoleh 27 orang yang tuntas dengan $71,1 \%$ dan 11 orang yang tidak tuntas dengan $28,9 \%$, dan pada siklus II dari 38 orang siswa diperoleh 35 orang yang tuntas dengan $92,1 \%$ dan 3 orang yang tidak tuntas dengan $7,8 \%$.

\section{DAFTAR PUSTAKA}

Aritonang, K. T. 2008. Minat dan Motivasi dalam Meningkatkan Hasil Belajar Siswa. Jurnal Pendidikan Penabur 7 (10):11-21

Asan, A \& Haliloglu, Z. (2005). Implementingproject based learning in computer classroom. The Turkish Online Journal of Education Technology-TOJET 4(2):11-12

Daryanto,2014. Pendekatan Pembelajaran saintifik kurikulum 2013. Yogyakarta: Penerbit : Gava Media,

M. Hosnan. 2013. Pendekatan Saintifik dan Kontekstual Dalam Pembelajaran Abad ke 21: Kunci sukses Implementasi Kurikulum 2013. Bogor: Ghalia Indonesia

Nadiroh. 2016. Penerapan model pembelajaran project based Learning (PJBL) untuk Meningkatkan Keterampilan Metakognitif Dan Hasil Belajar Biologi Siswa Kelas X4 SMAI Ma'arif Singosari - Malang - Jawa Timur. http://karya-

ilmiah.um.ac.id/index.php/biologi/article/vie $w / 5154$

Ridwan Abdullah Sani, 2014. Pembelajaran Saintifik Kurikulum 2013, (Jakarta: PT. Bumi Aksara. 